\title{
Biotransformed blueberry juice protects neurons from hydrogen peroxide-induced oxidative stress and mitogen-activated protein kinase pathway alterations
}

\author{
Tri Vuong ${ }^{1,2,3}$, Chantal Matar ${ }^{2,3}$, Charles Ramassamy ${ }^{2,4}$ and Pierre S. Haddad ${ }^{1,2 *}$ \\ ${ }^{1}$ Natural Health Products and Metabolic Diseases Laboratory, Department of Pharmacology and Montreal Diabetes Research \\ Center, University of Montreal, PO Box 6128, Downtown Station, Montreal, QC, Canada H3C $3 J 7$ \\ ${ }^{2}$ Institute of Nutraceuticals and Functional Foods, Laval University, Quebec City, QC, Canada \\ ${ }^{3}$ Department of Nutrition, Faculty of Health Sciences, University of Ottawa, Ottawa, ON, Canada \\ ${ }^{4}$ INRS-Institute Armand-Frappier, Laval, QC, Canada \\ (Received 26 January 2010 - Revised 8 March 2010 - Accepted 9 March 2010 - First published online 12 May 2010)
}

\begin{abstract}
A growing body of evidence supports the therapeutic effects of blueberry in neurodegenerative disorders. Biotransformation of blueberry juice by Serratia vaccinii bacteria increases its phenolic content and antioxidant activity. In neuronal cell culture, biotransformed blueberry juice (BJ) significantly increased the activity of antioxidant enzymes, namely catalase and superoxide dismutase. Moreover, BJ protected neurons against $\mathrm{H}_{2} \mathrm{O}_{2}$-induced cell death in a dose-dependent manner. This associated with the upregulation of mitogen-activated protein kinase (MAPK) family enzymes p38 and c-Jun N-terminal kinase (JNK) activation, as well as with the protection of extracellular signal-regulated kinase (ERK1/2) and MAPK/ERK kinase (MEK1/2) activity loss induced by $\mathrm{H}_{2} \mathrm{O}_{2}$. The present studies demonstrate that BJ can protect neurons against oxidative stress possibly by increasing antioxidant enzyme activities and activating p38- and JNK-dependent survival pathways while blocking MEK1/2- and ERK1/2-mediated cell death. Thus, BJ may represent a novel approach to prevent and to treat neurodegenerative disorders, and it may represent a source of novel therapeutic agents against these diseases.
\end{abstract}

Neuroprotection: Blueberry juice: Oxidative stress: Catalase: Mitogen-activated protein kinases

Oxidative neuronal cell damage has been implicated in the pathogenesis of neurodegenerative disorders such as Alzheimer's disease, Parkinson's disease and amyotrophic lateral sclerosis ${ }^{(1-4)}$. It is mediated by reactive oxygen species, including $\mathrm{H}_{2} \mathrm{O}_{2}$, superoxide anion and hydroxyl radicals, which are generated as by-products of normal and irregular metabolic processes. Reactive oxygen species attack cellular biomolecules and disrupt cellular function and membrane integrity, thereby leading to apoptosis ${ }^{(2,5,6)}$. As a major component of reactive oxygen species, $\mathrm{H}_{2} \mathrm{O}_{2}$ induces apoptosis in many different cell types, and therefore, it has been extensively used as an inducer of oxidative stress in in vitro models ${ }^{(7-9)}$.

Exposure to reactive oxygen species from a variety of sources has led organisms to develop a series of defence mechanisms. Such mechanisms involve prevention, repair, physical defence and antioxidant defence. Non-enzymatic antioxidants are represented by glutathione, ascorbic acid (vitamin C), $\alpha$-tocopherol (vitamin E) and carotenoids. Enzymatic antioxidant defence includes superoxide dismutase (SOD), glutathione peroxidase and catalase $(\mathrm{CAT})^{(10)}$. However, the effects of SOD may become deleterious when it is overexpressed because of the resulting $\mathrm{H}_{2} \mathrm{O}_{2}$ production ${ }^{(11)}$.

The mitogen-activated protein kinase (MAPK) family plays a critical role in the cellular response to a wide range of stimuli. Indeed, the dynamic balance between branches of the MAPK family, namely extracellular signal-regulated kinase (ERK1/2), c-Jun N-terminal kinase (JNK) and p38 MAPK, is implicated in regulating cell death/survival ${ }^{(10,12)}$. Several mechanisms are involved in the specificity of different, even opposing signals of the MAPK family, including (i) duration and strength of the signal, (ii) interaction with various scaffold proteins, (iii) subcellular localisation, (iv) presence of several isoforms, (v) extensive cross-talk and interplay between MAPK cascade and other pathways; (vi) post-translational modifications other than phosphorylation ${ }^{(13)}$. Furthermore, the spatial distribution and temporal qualities of MAPK can markedly alter the qualitative and quantitative features of downstream signalling to immediate early genes and the expression of immediate early genes-encoded protein products. As a result, immediate early gene products provide

Abbreviations: BJ, biotransformed blueberry juice; CAT, catalase; ERK, extracellular signal-regulated kinase; JNK, c-Jun N-terminal kinase; MAPK, mitogen-activated protein kinase; MEK, MAPK/ERK kinase; SOD, superoxide dismutase; NJ, normal blueberry juice; TBST, Tris-buffered saline Tween-20; WST-1, water-soluble tetrazolium salt-1.

* Corresponding author: Dr Pierre S. Haddad, fax +1 514343 2291, email pierre.haddad@umontreal.ca 
a molecular interpretation of MAPK dynamics, enabling the cell to program an appropriate biological response ${ }^{(12)}$.

Natural antioxidants have been reported to play a major role in blocking oxidative stress induced by free radicals. Supplementation with fruits and vegetables rich in polyphenols is beneficial for both forestalling and reversing the deleterious effects of ageing on neuronal communication and behaviour $^{(14-17)}$. The observed protection may be due to the antioxidant and anti-inflammatory properties of the polyphenolic compounds found in these fruits and vegetables ${ }^{(9,18-20)}$.

Blueberries show the highest antioxidant capacity among all fruits and vegetables ${ }^{(21)}$. Blueberries and their phenolic compounds, such as anthocyanins and flavonoids, have been identified as potential contributors of amelioration of neuronal cell dysfunction $^{(22-25)}$. Biotransformation of blueberry juice with a novel strain of bacteria isolated from the blueberry flora and named Serratia vaccinii increases its phenolic content and antioxidant activity ${ }^{(26)}$. It also modifies the biological activity of biotransformed blueberry juice (BJ), such as inhibiting NO production in macrophages ${ }^{(27)}$ and increasing its antiobesity and antidiabetic effects ${ }^{(28,29)}$. The aim of the present study was to assess the neuroprotective property of BJ against $\mathrm{H}_{2} \mathrm{O}_{2}$-induced oxidative stress in cultured neuronal cells.

\section{Materials and methods}

\section{Preparation of fermented blueberry juice}

Mature lowbush blueberries (Vaccinium angustifolium Ait.) were purchased from Cherryfield Foods, Inc. (Cherryfield, ME, USA) as fresh and untreated fruits. Blueberry juice was extracted by blending the fruits $(100 \mathrm{~g})$ in a Braun Type 4259 food processor with an equivalent quantity (100 g) of Minimal Broth Davis without dextrose (Difco Laboratories, Detroit, MI, USA). The fruit mixture was then centrifuged at $500 \mathrm{~g}$ for $6 \mathrm{~min}$ to remove fruit skin and insoluble particles. The resulting juice was sterilised using $0 \cdot 22 \mu \mathrm{m}$ Express Millipore filters (Millipore, Etobicoke, ON, Canada).

Serratia vaccinii bacteria were cultured as described previously ${ }^{(26)}$. The juice was inoculated with a saturated culture of Serratia corresponding to $2 \%$ of the total juice volume. After a $4 \mathrm{~d}$ fermentation period, the transformed juice was sterilised by $0.22 \mu \mathrm{m}$ filtration. The total phenolic content was then measured by the Folin-Ciocalteau method using gallic acid as the standard, and hence expressed as $\mu \mathrm{M}$ gallic acid equivalent. The total phenolic content was increased from 4581 to $19338 \mu \mathrm{M}$-gallic acid equivalent, confirming successful transformation. Normal blueberry juice (NJ) and BJ have been partially characterised as described elsewhere ${ }^{(26,30)}$.

\section{Cell culture}

Murine N2a neuroblastoma cell line was obtained from the American Type Cell Collection (Chicago, IL, USA). Cells were cultured in minimum essential medium containing fetal bovine serum (10\%, v/v; Sigma-Aldrich, Oakville, ON, Canada) and penicillin/streptomycin $(0.05 \mathrm{mg} / \mathrm{ml})$ at $37^{\circ} \mathrm{C}$ in a humidified atmosphere with $5 \% \mathrm{CO}_{2}$ in twenty-four-well plates for viability and toxicity experiments, twelve-well plates for SOD activity experiments and six-well plates for enzyme activity and signalling experiments.

\section{Viability and toxicity assay}

Cell viability was assessed by water-soluble tetrazolium salt-1 (WST-1) assay (Roche, Laval, QC, Canada). Briefly, after pretreatments with blueberry juices, $\mathrm{H}_{2} \mathrm{O}_{2}$ was added at a final concentration of $0.75 \mathrm{~mm}$ for $24 \mathrm{~h}$. WST-1 was added $(10 \%, \mathrm{v} / \mathrm{v})$ and incubated at $37^{\circ} \mathrm{C}$ for $2 \mathrm{~h}$. The absorbance was measured at $450 \mathrm{~nm}$ in a plate reader (Wallac Victor 2; Perkin-Elmer, St-Laurent, QC, Canada).

In preliminary experiments, $\mathrm{H}_{2} \mathrm{O}_{2}$ induced a $30-35 \%$ cell loss at $0.75 \mathrm{~mm}$. This concentration was used for all the experiments thereafter. The protective effect of BJ was maximised if cells were pretreated with $\mathrm{BJ}$ for $1 \mathrm{~h}$ before adding $\mathrm{H}_{2} \mathrm{O}_{2}$.

Cell toxicity was measured by lactate dehydrogenase assay (Roche). After treatments, $100 \mu \mathrm{l}$ of the culture medium were transferred to a ninety-six-well plate. Cells were lysed with $0 \cdot 1 \mathrm{M}-\mathrm{NaOH}$ for $10 \mathrm{~min}$ on ice, and $100 \mu \mathrm{l}$ of lysate were transferred to a ninety-six-well plate. One hundred microlitres of assay mixture were added to each well, and incubated at room temperature for $10 \mathrm{~min}$. The absorbance was measured at $450 \mathrm{~nm}$.

\section{GSH:GSSG ratio}

GSH:GSSG ratio was measured using BIOXYTECH GSH/ GSSG-412 ${ }^{\mathrm{TM}}$ kit (OxisResearch ${ }^{\mathrm{TM}}$, Foster City, CA, USA). After treatments, cells were placed on ice and washed twice with ice-cold Krebs phosphate buffer. Twenty microlitres of scavenger were added to GSSG sample, while $20 \mu$ of buffer were added to GSH sample. Cells were then lysed in $200 \mu \mathrm{l}$ of lysis buffer (50 mM-Tris- $\mathrm{HCl}$ (pH 7.5)/0.5\% Triton X-100). Lysed cells were scraped and transferred to microcentrifuge tubes. Samples were allowed to lyse for an additional $15 \mathrm{~min}$ on ice with periodic vortexing. The lysates were centrifuged at $300 \mathrm{~g}$ at $4^{\circ} \mathrm{C}$ for $10 \mathrm{~min}$, and the samples were used for determination of GSH:GSSG ratio according to the manufacturer's instructions.

\section{Enzymatic activity assay}

SOD enzyme activity was measured using the SOD Assay Kit-WST (Dojindo Molecular Technologies, Inc., Gaithersburg, MD, USA). After treatments, cells were placed on ice and washed twice with ice-cold Krebs phosphate buffer. Cells were lysed in $200 \mu \mathrm{l}$ of lysis buffer $(50 \mathrm{~mm}$-Tris- $\mathrm{HCl}(\mathrm{pH}$ $7 \cdot 5) / 0 \cdot 5 \%$ Triton X-100). Lysed cells were then scraped and transferred to microcentrifuge tubes. Samples were allowed to lyse for an additional $15 \mathrm{~min}$ on ice with periodic vortexing. The lysates were centrifuged at $300 \mathrm{~g}$ at $4^{\circ} \mathrm{C}$ for $10 \mathrm{~min}$, and $20 \mu$ of this sample solution were used for determination of SOD enzyme activity according to the manufacturer's instructions. CAT activity was determined by adding $900 \mu \mathrm{l}$ of $30 \mathrm{mM}-\mathrm{H}_{2} \mathrm{O}_{2}$ to $100 \mu \mathrm{l}$ of the cell lysate. The disappearance of $\mathrm{H}_{2} \mathrm{O}_{2}$ was monitored at $240 \mathrm{~nm}$ for $1 \mathrm{~min}$.

\section{Western blot analysis}

After treatments, cells were placed on ice and washed three times with ice-cold Krebs phosphate buffer. Cells were lysed in radioimmunoprecipitation assay lysis buffer $(50 \mathrm{~mm}$ HEPES, pH 7.4, 150 mm-NaCl, 5 mm-EDTA, 2 mM- $\mathrm{MgCl}_{2}$, 
$1 \%$ Triton $\mathrm{X}-100,1 \%$ sodium deoxycholate and $0.1 \%$ SDS) containing protease inhibitors (2 mM-phenylmethylsulphonylflouride and Complete Mini protease inhibitor cocktail tablets (Roche)) and phosphatase inhibitors (0.5 mM-NaF, $2 \mathrm{~mm}-$ sodium orthovanadate and $1 \mathrm{~mm}$-sodium pyrophosphate). Lysed cells were then scraped and transferred to microcentrifuge tubes. Samples were allowed to lyse for an additional $15 \mathrm{~min}$ on ice with periodic vortexing. Lysates were then centrifuged at $4500 \mathrm{~g}$, and supernatants were collected and stored at $-80^{\circ} \mathrm{C}$ until further analysis.

Protein concentration of lysates was assessed using the bicinchoninic acid colorimetric method (Pierce, Rockford, IL, USA) according to the manufacturer's instructions. From each sample, $120 \mu \mathrm{g}$ of total protein were loaded onto an $8 \%$ acrylamide gel, and were separated at $4^{\circ} \mathrm{C}$ for $3 \mathrm{~h}$ at $75 \mathrm{~mA}$, followed by $15 \mathrm{~h}$ at $20 \mathrm{~mA}$, using a Protean II electrophoresis apparatus (BioRad, Missisauga, ON, Canada). Separated samples were then electrotransferred onto polyvinylidene fluoride membranes (Millipore) at $4^{\circ} \mathrm{C}$ for $90 \mathrm{~min}$ at $1 \mathrm{~A}$ using a Transblot apparatus (BioRad). Membranes were stained with Ponceau red solution (5\%, in acetic acid; Sigma) and photographed, and were then washed in Tris-buffered saline Tween-20 (TBST, $50 \mathrm{~mm}$-Tris, $\mathrm{pH} 7.4,150 \mathrm{~mm}-\mathrm{NaCl}$ and $0.5 \%$ Tween-20) followed by blocking in TBST $+5 \%$ non-fat dried milk for $1 \mathrm{~h}$ at ambient temperature. Membranes were incubated overnight at $4^{\circ} \mathrm{C}$ with the following antibodies: rabbit anti-phospho-mitogenactivated protein kinase/extracellular signal-regulated kinase kinase (MEK1/2; Ser217/221), rabbit anti-phospho-p38 MAPK (Thr180/Tyr182), mouse anti-phospho-ERK1/2 (Thr202/Tyr204) and rabbit anti-phospho-stress-activated protein kinase (SAPK)/ JNK (Thr183/Tyr185) (cat \#9121, \#9211, \#4377, \#9251, respectively; Cell Signaling Technology, Incorporation, Danvers, MA, USA) at 1:1000 dilution in TBST $+5 \%$ bovine serum albumin. Membranes were then incubated for $60 \mathrm{~min}$ at ambient temperature with horseradish peroxidase-conjugated anti-rabbit or anti-mouse secondary antibodies (Jackson Immunoresearch Laboratories, Incorporation, West Grove, PA, USA) at 1:100000 dilution in TBST $+5 \%$ milk. After washing with TBST, the blots were revealed using the enhanced chemiluminescence method (Amersham, Piscataway, NJ, USA) on a blue-light-sensitive film (Amersham). Densitometric analysis was performed using a Hewlett-Packard flatbed scanner and NIH software Image J $1.37 \mathrm{v}$.

\section{Statistical analysis}

Statistical analysis of the data by two-way ANOVA and Fisher's post hoc tests was performed using StatView software (Cary, NC, USA). Statistical significance was set at $P \leq 0.05$. Data are reported as mean values with their standard errors.

\section{Results}

\section{Biotransformed blueberry juice protects neurons against hydrogen peroxide-induced cell death}

To investigate the potential protective effects of blueberry juices in vitro, $\mathrm{N} 2 \mathrm{a}$ neuroblastoma cells were treated with $\mathrm{H}_{2} \mathrm{O}_{2}$ in their presence or absence. $\mathrm{H}_{2} \mathrm{O}_{2}$ alone induced significant loss of cell viability in a dose-dependent manner (data not shown), whereas sterile $\mathrm{BJ}$ or $\mathrm{NJ}$ alone were non-toxic.

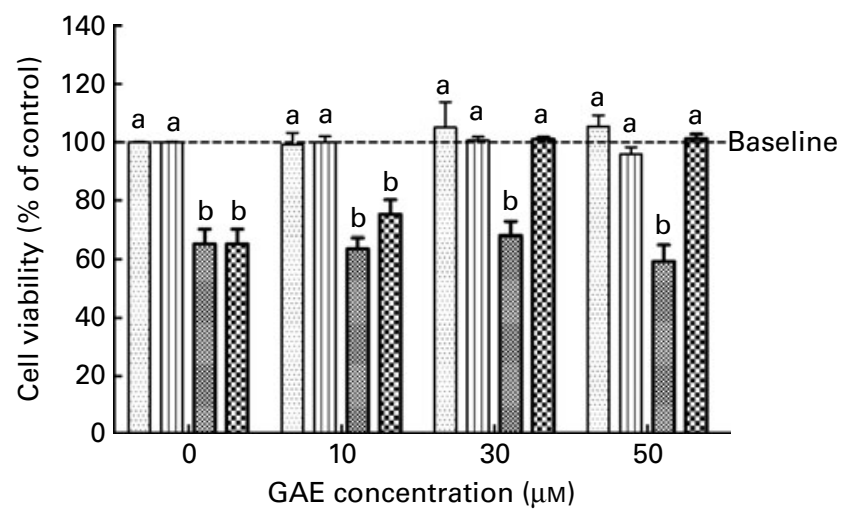

Fig. 1. Effect of $0.75 \mathrm{~mm}$-hydrogen peroxide (HP) on N2a cell viability after pretreatment with either 0,10 or $30 \mu \mathrm{M}$-gallic acid equivalent (GAE) of normal blueberry juice (NJ) or biotransformed blueberry juice (BJ) by water-soluble tetrazolium salt-1. All values are means of four separate experiments with their standard errors. ${ }^{a, b}$ Mean values with unlike letters were significantly different $(P<0.05$; two-way ANOVA). $: 0, \mathrm{NJ}$; m, BJ; $\mathrm{w}, \mathrm{NJ}+\mathrm{HP} ; \mathrm{g}, \mathrm{BJ}+\mathrm{HP}$.

Co-treatment with $\mathrm{BJ}$ significantly protected neurons against $\mathrm{H}_{2} \mathrm{O}_{2}$-induced oxidative stress in a dose-dependent manner, and completely abolished $\mathrm{H}_{2} \mathrm{O}_{2}$ toxicity from a concentration of $30 \mu \mathrm{M}$-gallic acid equivalent onwards, whereas $\mathrm{NJ}$ did not show any effect (Fig. 1).

Because the WST-1 assay is based on mitochondrial activity and the latter can be affected by plant polyphenolic compounds $^{(31)}$, we confirmed the present results with the lactate dehydrogenase assay. Again, $\mathrm{H}_{2} \mathrm{O}_{2}$ induced dosedependent neuronal cell death that was countered by BJ but not by NJ (Fig. 2).

\section{Biotransformed blueberry juice preserves GSH/GSSG balance}

Neither NJ nor BJ alone affected the GSH:GSSG ratio, whereas $\mathrm{H}_{2} \mathrm{O}_{2}$ significantly decreased GSH:GSSG ratio by $19 \%$ after $30 \mathrm{~min}$ and by $21 \%$ after $4 \mathrm{~h}$. However, $\mathrm{H}_{2} \mathrm{O}_{2}$ significantly lost its tendency to reduce the GSH:GSSG ratio in BJ-pretreated neurons, while no significant difference was observed in NJ-pretreated cells (Fig. 3).

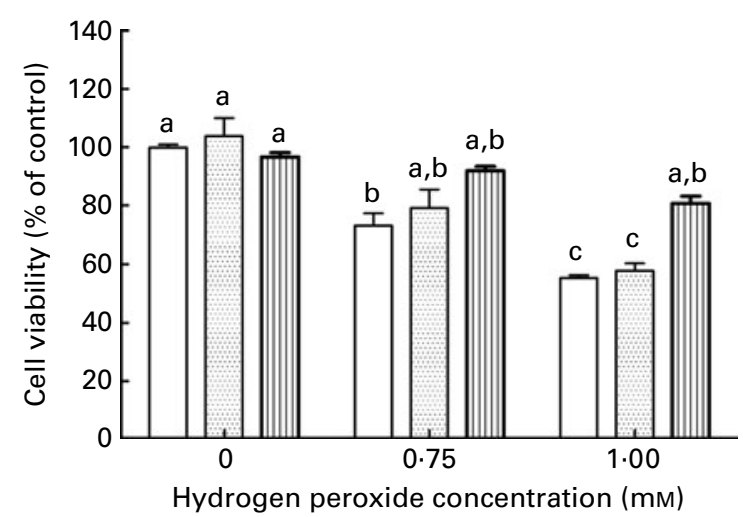

Fig. 2. Effect of $0.75 \mathrm{~mm}$-hydrogen peroxide (HP) on N2a cell viability after pretreatment with $30 \mu \mathrm{M}$-gallic acid equivalent of normal blueberry juice (NJ) or biotransformed blueberry juice (BJ) by lactate dehydrogenase. All values are means of four separate experiments with their standard errors. ${ }^{a, b, c}$ Mean values with unlike letters were significantly different $(P<0.05$; two-way ANOVA). $\square$, Control; 圈, NJ; 血, BJ. 


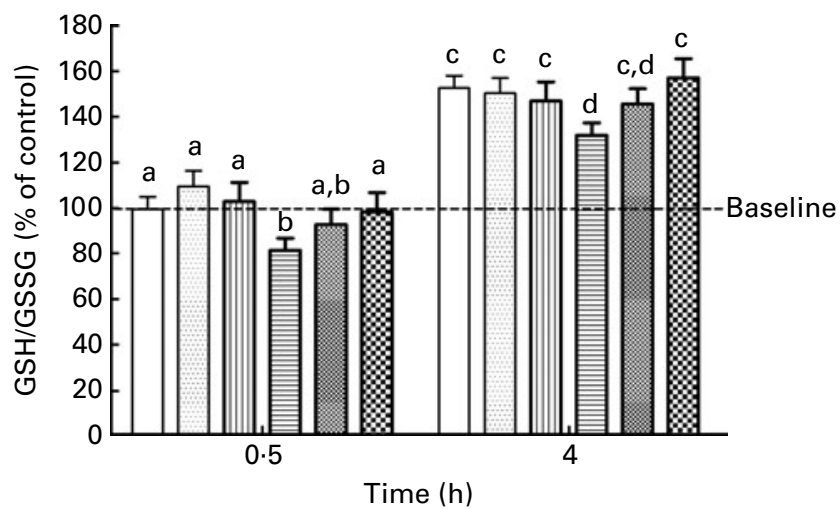

Fig. 3. GSH:GSSG ratio in N2a cells after treatment with $0.75 \mathrm{~mm}$-hydrogen peroxide (HP) for 0.5 and $4 \mathrm{~h}$. All values are means of three separate experiments with their standard errors. ${ }^{a-d}$ Mean values with unlike letters were significantly different $(P<0.05$; two-way ANOVA). $\square$, Control; $\square$, normal blue-

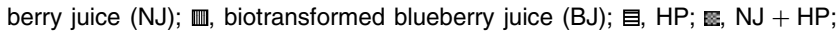
G, BJ + HP.

\section{Biotransformed blueberry juice increases catalase and} superoxide dismutase activities

When administered alone, BJ increased CAT activity in $\mathrm{N} 2 \mathrm{a}$ cells. CAT activity reached the highest level after a $4 \mathrm{~h}$ treatment $(0.13$ (SEM 0.02) v. 0.09 (SEM 0.01) mM/min per $\mathrm{mg}$ protein, $4 v .0 \mathrm{~h}, P<0 \cdot 05$ ), and then gradually decreased towards control values (Fig. 4). In contrast, control and NJ-treated cells displayed a rather stable CAT activity over the $24 \mathrm{~h}$ experimental period. When $\mathrm{H}_{2} \mathrm{O}_{2}$ alone was added, CAT activity increased rapidly and reached the highest level after $24 \mathrm{~h}(0 \cdot 13$ (SEM 0.02) v. 0.08 (SEM 0.01) mM/min per mg protein, $\mathrm{H}_{2} \mathrm{O}_{2} v$. control at $24 \mathrm{~h}, P<0 \cdot 05)$. Neither BJ nor NJ treatment could significantly affect $\mathrm{H}_{2} \mathrm{O}_{2}$ actions even though BJ treatment had lowered $\mathrm{H}_{2} \mathrm{O}_{2}$-increased CAT activity (Fig. 4).

$\mathrm{BJ}$, but not $\mathrm{NJ}$, rapidly and significantly increased SOD activity when administered alone (Fig. 5). However, SOD activity returned to the basal level after $24 \mathrm{~h} . \mathrm{H}_{2} \mathrm{O}_{2}$ by itself gradually increased SOD activity. SOD activity reached the highest level after $4 \mathrm{~h}$, and then remained constant at this level. When $\mathrm{H}_{2} \mathrm{O}_{2}$ was added to BJ-treated cells, SOD activity was slightly increased, and then returned to the basal level

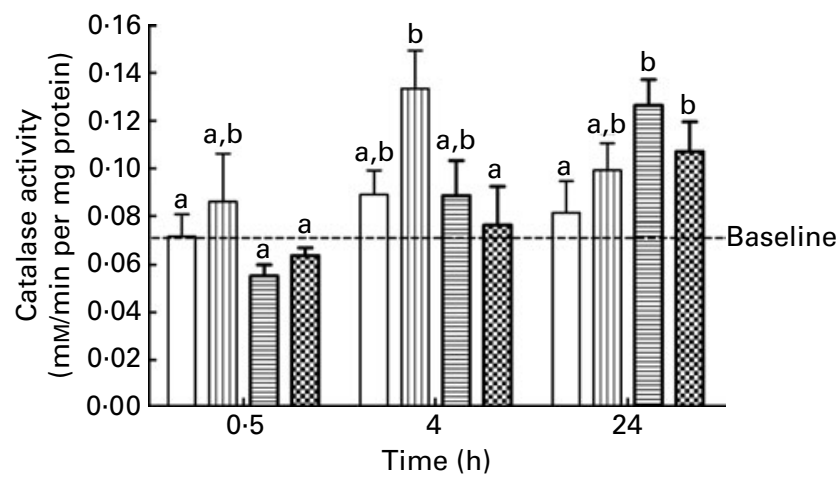

Fig. 4. Catalase activity in N2a cells after treatment with $0.75 \mathrm{~mm}$-hydrogen peroxide $(\mathrm{HP})$ for 0,4 and $24 \mathrm{~h}$. All values are means of three separate experiments with their standard errors. ${ }^{\mathrm{a}, \mathrm{b}}$ Mean values with unlike letters were significantly different $(P<0.05$; two-way ANOVA). $\square$, Control; 血, biotransformed blueberry juice (BJ); 目, HP; $\mathrm{Q}, \mathrm{BJ}+\mathrm{HP}$.

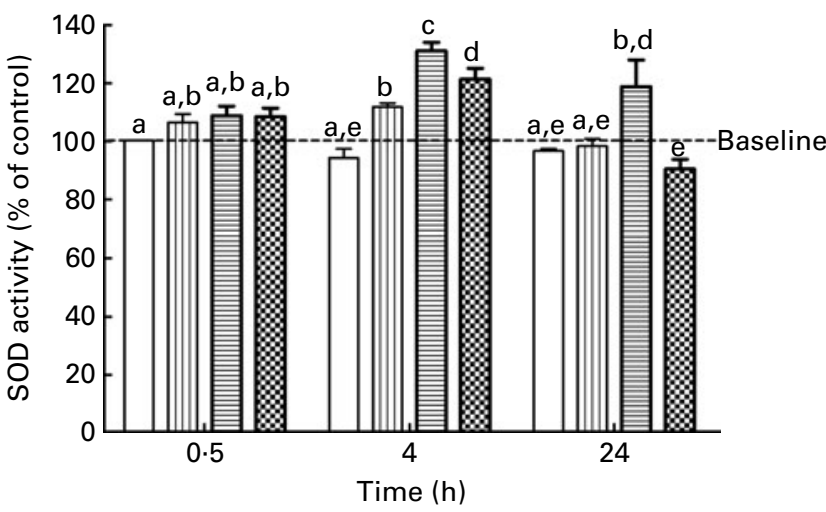

Fig. 5. Superoxide dismutase (SOD) activity in N2a cells after treatment with hydrogen peroxide (HP) for 0,4 and $24 \mathrm{~h}$. All values are means of three separate experiments with their standard errors. ${ }^{a-e}$ Mean values with unlike letters were significantly different $(P<0.05$; two-way ANOVA). $\square$, Control; 血, biotransformed blueberry juice (BJ); 目, HP; $\mathbf{\theta}, \mathrm{BJ}+\mathrm{HP}$

after $24 \mathrm{~h}$ (Fig. 5). As for CAT, NJ pretreatment did not show any effect (data not shown).

Biotransformed blueberry juice protection is associated with the activation of c-Jun N-terminal kinase and mitogenactivated protein kinase p38

Exposure of $\mathrm{N} 2 \mathrm{a}$ cells to $\mathrm{BJ}$ alone triggered the activation of both p38 MAPK (Fig. 6) and JNK (Fig. 7), while NJ did not show any effect compared with the vehicle control. BJ induced maximal phosphorylation of p38 MAPK by $90 \%$ after $30 \mathrm{~min}$ (Fig. 6), and of JNK by $66 \%$ after $2 \mathrm{~h}$ (Fig. 7). While $\mathrm{H}_{2} \mathrm{O}_{2}$ did not modify JNK phosphorylation (Fig. 7), it

\section{Phospho-p38 MAPK (38 kDa)}
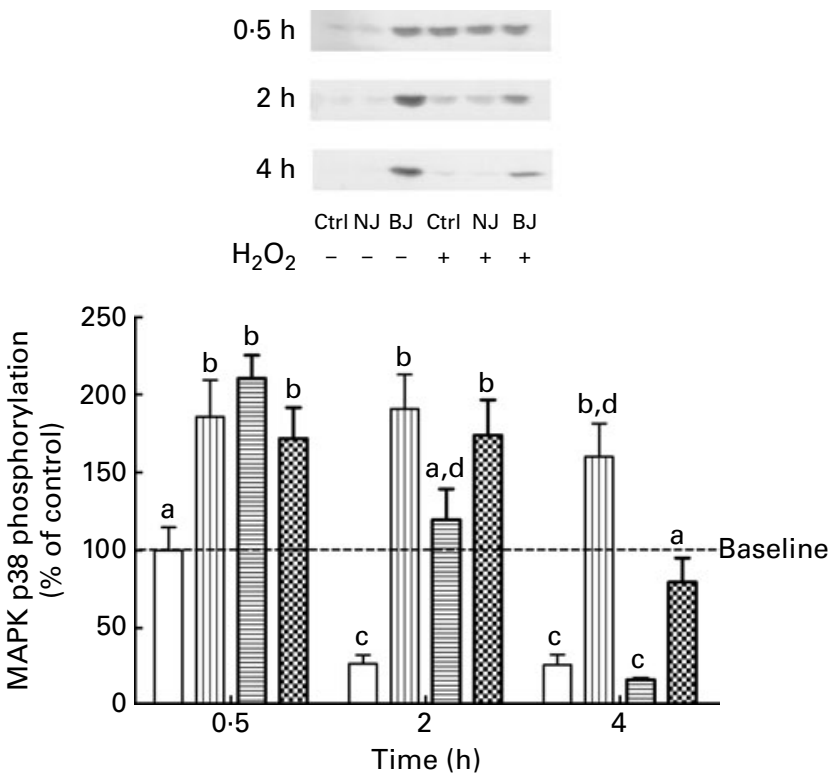

Fig. 6. Phosphorylation of p38 mitogen-activated protein kinase (MAPK) in $\mathrm{N} 2 \mathrm{a}$ cells after treatment with $0.75 \mathrm{~mm}$-hydrogen peroxide (HP) for $0.5,2$ and $4 \mathrm{~h}$. All values are means of four separate Western blot experiments with their standard errors. ${ }^{a-d}$ Mean values with unlike letters were significantly different $(P<0.05$; two-way ANOVA). $\square$, Control (ctrl); 四, biotransformed blueberry juice (BJ); 目, HP; ⿴囗 BJ + HP. 


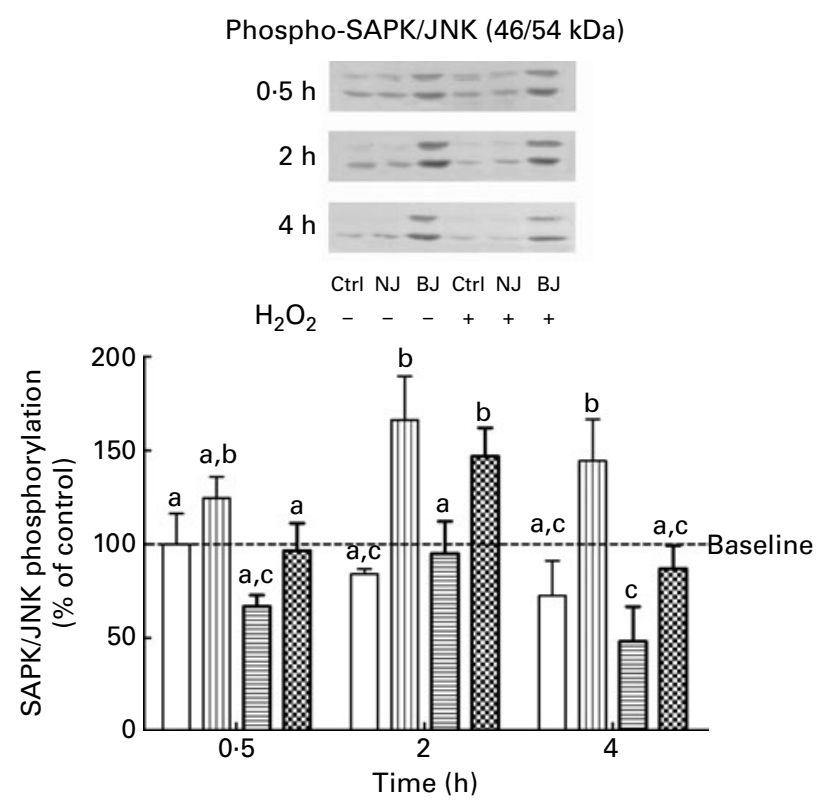

Fig. 7. Phosphorylation of c-Jun N-terminal kinase (JNK) in N2a cells after treatment with $0.75 \mathrm{~mm}$-hydrogen peroxide $(\mathrm{HP})$ for $0.5,2$ and $4 \mathrm{~h}$. All values are means of four separate Western blot experiments with their standard errors. ${ }^{a, b, c}$ Mean values with unlike letters were significantly different $(P<0.05$; two-way ANOVA). $\square$, Control; 四, biotransformed blueberry juice (BJ); 目, HP; : BJ + HP. SAPK, stress-activated protein kinase; NJ, normal blueberry juice.

increased p38 MAPK activity by $111 \%$ after $30 \mathrm{~min}$, which then gradually decreased to a very low level after $4 \mathrm{~h}(19 \%$ of time 0 control, Fig. 6). In BJ-treated cells challenged with $\mathrm{H}_{2} \mathrm{O}_{2}$, p38 MAPK and JNK activities followed the
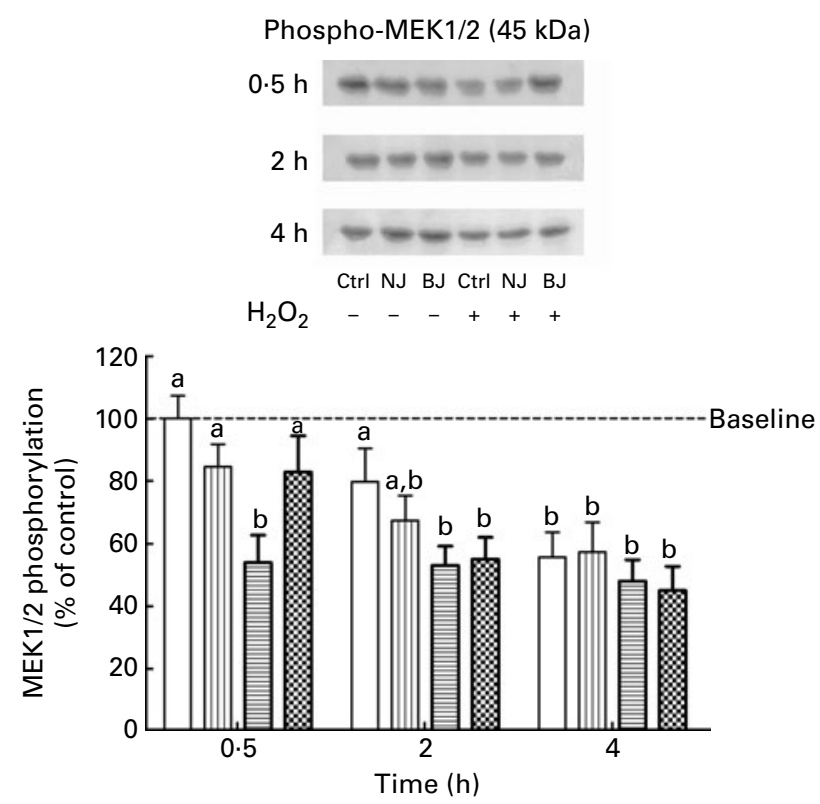

Fig. 8. Phosphorylation of mitogen-activated protein kinase/extracellular signal-regulated kinase (MEK) $1 / 2$ in N2a cells after treatment with $0.75 \mathrm{~mm}$ hydrogen peroxide (HP) for $0.5,2$ and $4 \mathrm{~h}$. All values are means of three separate Western blot experiments with their standard errors. ${ }^{\mathrm{a}, \mathrm{b}}$ Mean values with unlike letters were significantly different $(P<0.05$; two-way ANOVA). $\square$, Control (ctrl); 四, biotransformed blueberry juice (BJ); 目, HP; Q, BJ + HP; NJ, normal blueberry juice.
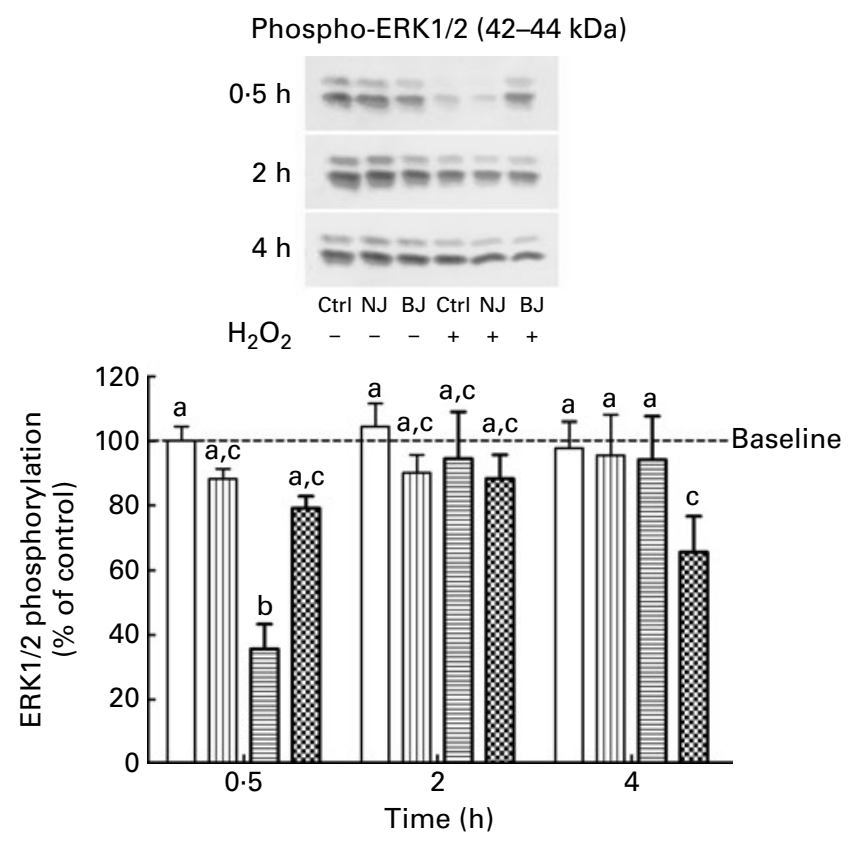

Fig. 9. Phosphorylation of ERK1/2 in N2a cells after treatment with $0.75 \mathrm{~mm}-$ hydrogen peroxide (HP) for $0.5,2$ and $4 \mathrm{~h}$. All values are means of three separate Western blot experiments with their standard errors. ${ }^{\mathrm{a}, \mathrm{b}, \mathrm{c}}$ Mean values with unlike letters were significantly different $(P<0.05$; two-way ANOVA). $\square$, Control (ctrl); 血, biotransformed blueberry juice (BJ); 目, HP; Q, BJ + HP; NJ, normal blueberry juice.

same pattern observed in cells treated with $\mathrm{BJ}$ alone, albeit at a slightly lower level, hence indicating a significant dampening of $\mathrm{H}_{2} \mathrm{O}_{2}$ effects (Figs. 6 and 7). For both enzymes, NJ treatment gave results indistinguishable from those observed for vehicle control or $\mathrm{H}_{2} \mathrm{O}_{2}$ groups, respectively (data not shown).

Biotransformed blueberry juice inhibition of hydrogen peroxide toxicity is associated with the protection of mitogen-activated protein kinaselextracellular signal-regulated kinase kinase1/2 and extracellular signal-regulated kinase1/2 activities

Baseline MEK1/2 phosphorylation exhibited a gradual and steady decline within the $4 \mathrm{~h}$ experimental period, and this was not affected by either NJ or BJ treatments (Fig. 8). In contrast, ERK1/2-activated state remained stable in control and $\mathrm{NJ}$ - and BJ-treated groups (Fig. 9). When $\mathrm{H}_{2} \mathrm{O}_{2}$ was added to N2a cells, MEK1/2 and ERK1/2 phosphorylations were rapidly and significantly decreased by half within 30 min (Figs. 8 and 9). ERK1/2 then gradually increased to the initial level by $2 \mathrm{~h}$, while MEK1/2 remained stable at its new low level. In BJ-treated cells, there were no significant changes in MEK1/2 and ERK1/2 activities induced by $\mathrm{H}_{2} \mathrm{O}_{2}$ (Figs. 8 and 9).

\section{Discussion}

Blueberry and blueberry products have been demonstrated to possess the potential to reduce age-related neurodegeneration and to enhance motor and cognitive functions ${ }^{(14,17)}$. Our group has discovered a bacterium from the blueberry flora 
that can biotransform blueberry juice ${ }^{(26)}$. This greatly accentuates its antioxidant potential ${ }^{(26,32)}$, and endows it with novel anti-inflammatory ${ }^{(27)}$ and antidiabetic ${ }^{(28,29)}$ biological activities. In the present study, we sought to explore the effect of such a biotransformation on the neuroprotective potential of blueberry juice. We chose $\mathrm{H}_{2} \mathrm{O}_{2}$ as a source of oxidative stress because it is formed endogenously as a natural by-product of enzymatic oxidase action or as a product of the dismutation of superoxide anion catalysed by $\mathrm{SOD}^{(3)}$. It contributes to the background level of cellular oxidative stress $^{(33)}$. It is generally accepted that the antioxidant enzymes CAT and glutathione peroxidase can protect cells from the effects of basal $\mathrm{H}_{2} \mathrm{O}_{2}$ production ${ }^{(34)}$. The administration of exogenous $\mathrm{H}_{2} \mathrm{O}_{2}$ can elevate oxidative stress beyond the protective capacities of endogenous antioxidant defence systems, resulting in apoptosis or necrosis of cultured neurons ${ }^{(35)}$.

We also chose murine neuroblastoma cells of the N2a line because they have been widely employed to investigate the antioxidant mechanisms involved in neurotoxicity, neuroprotection and neuronal repair ${ }^{(8,36,37)}$. In the present study, $\mathrm{H}_{2} \mathrm{O}_{2}(0.75 \mathrm{~mm})$ caused a significant decrease in cell viability (35\%), but pretreatment of $\mathrm{N} 2 \mathrm{a}$ cells with $\mathrm{BJ}$ blocked this oxidative stress-induced cytotoxicity in a dose-dependent manner. Similar protection was not found with NJ.

One of the first-line defence mechanisms against $\mathrm{H}_{2} \mathrm{O}_{2}$ induced toxicity is the antioxidant enzyme CAT. We found that BJ treatment alone significantly increased CAT activity by $44 \%$, and this was consistent with the parallel protection of neuronal cells against oxidative stress attack by $\mathrm{H}_{2} \mathrm{O}_{2}$. The mechanism through which $\mathrm{BJ}$ increased CAT activity is unknown. However, since the increase in CAT activity in $\mathrm{BJ}$-treated neurons required at least $4 \mathrm{~h}$ to be fully expressed, BJ might act via both transcriptional and translational mechanisms.

Another important enzymatic antioxidant defence mechanism involves SOD. Indeed, upregulation of SOD activity has been associated with neuroprotective capabilities in certain studies $^{(38)}$. However, since SOD-catalysed reactions also elevate endogenous $\mathrm{H}_{2} \mathrm{O}_{2}$, overexpression of SOD can also cause deleterious effects ${ }^{(11)}$. In fact, excessive $\mathrm{H}_{2} \mathrm{O}_{2}$ production caused by SOD overexpression has been implicated in the brain injury observed after perinatal hypoxia-ischaemia ${ }^{(39)}$. In our study, $\mathrm{H}_{2} \mathrm{O}_{2}$ clearly increased $\mathrm{SOD}$ activity, which was maintained at a high level over $24 \mathrm{~h}$. This may appear paradoxical, but it could simply be indicative of the state of oxidative stress induced in neuronal cells by our experimental conditions. When cells were pretreated with $\mathrm{BJ}$, however, the rise that $\mathrm{H}_{2} \mathrm{O}_{2}$ induced in SOD activity was blunted, and the activity returned to normal levels within $24 \mathrm{~h}$. These results further support the notion that BJ protected neurons from $\mathrm{H}_{2} \mathrm{O}_{2}$-induced oxidative stress.

Apart from enzymatic antioxidant system, non-enzymatic protective mechanisms exist, one of the most important being the GSH:GSSG system ${ }^{(10)}$. In our experimental conditions, GSH:GSSG ratio was reduced by $\mathrm{H}_{2} \mathrm{O}_{2}$ treatment, as expected if oxidative stress overcomes the capacity of this antioxidant system. In cells pretreated with BJ, this reduction of GSH:GSSG ratio was lost. Surprisingly, BJ alone did not modulate the GSH:GSSG ratio, and similarly, it had no impact on GSH production (data not shown). One can speculate that GSH reductase and GSH peroxidase activities have been modulated by BJ, and further studies are necessary to address this point. Nonetheless, it is well known that phenolic compounds, such as quercetin, epicatechin, mangiferin, patuletin, nepetin, and axillarin, can increase both GSH reductase and GSH peroxidase activities ${ }^{(40-42)}$.

Although $\mathrm{H}_{2} \mathrm{O}_{2}$ has been widely used to study the underlying molecular mechanisms of neurotoxicity and neuroprotection in N2a cells, detailed information on the cell death pathways involved is still lacking, notably at the level of the three branches of the MAPK family, namely ERK1/2, JNK, and p38 MAPK. The present study investigated the kinetics of these members of the MAPK family after $\mathrm{H}_{2} \mathrm{O}_{2}$ challenge. To our knowledge, this has not been reported previously in the $\mathrm{N} 2 \mathrm{a}$ cell system.

We found that $\mathrm{H}_{2} \mathrm{O}_{2}$ first induced a transient inactivation of both JNK and ERK1/2 while increasing p38 MAPK activity within $30 \mathrm{~min}$. Then, ERK1/2 activity gradually returned to basal levels by $4 \mathrm{~h}$, whereas both JNK and p38 MAPK activities were decreased to exhibit prolonged inactivation after $4 \mathrm{~h}$. Both transient activation of p38 MAPK and prolonged activation of ERK1/2 have been correlated with $\mathrm{H}_{2} \mathrm{O}_{2}$-induced neurotoxicity in $\mathrm{PC} 12$ cells ${ }^{(43,44)}$.

The mechanisms by which $\mathrm{H}_{2} \mathrm{O}_{2}$ decreased both JNK and ERK1/2 phosphorylations are unknown. However, since MEK1/2 phosphorylation was also observed to decrease, this inactivation may be regulated by phosphatases with or without cross-talk between MAPK pathways. Recently, dual-specificity phosphatases, generally termed MAPK phosphatases, were found to control the spatiotemporal regulation of ERK1/2 and cross-talk between MAPK pathways ${ }^{(45)}$. Further studies are necessary to clarify the involvement of MAPK phosphatases in the effects observed herein.

$\mathrm{NJ}$ did not show any effect on either basal or $\mathrm{H}_{2} \mathrm{O}_{2}$-induced MAPK member phosphorylations, and results were generally similar to the respective controls. In contrast, pretreatment with BJ rapidly increased basal p38 and JNK phosphorylations, which remained elevated for up to $4 \mathrm{~h}$. Conversely, BJ did not have any influence on the basal behaviour of MEK1/2 or ERK phosphorylation observed in vehicle controls over the $4 \mathrm{~h}$ experimental period. In general, BJ significantly reduced the initial changes in the MAPK family member phosphorylation state described earlier after treatment with $\mathrm{H}_{2} \mathrm{O}_{2}$. Therefore, modifications in MAPK family enzymes appear to contribute to the protection of neurons against $\mathrm{H}_{2} \mathrm{O}_{2}$ induced cell death afforded by BJ. Indeed, although the role of JNK and p38 MAPK in apoptosis has been established in some cell lines, they have also been shown to contribute to survival, development and differentiation depending on their active isoform $^{(13)}$. For examples, JNK1 and JNK2 were initially believed to possess redundant functions; however, it was found that JNK1 preferentially mediates apoptosis, whereas JNK2 is associated with cellular proliferation ${ }^{(46)}$. Similarly, MAPK p38 $\alpha$ and p38 $\beta$ are involved in apoptosis, whereas MAPK p38 $\gamma$ and p38 $\theta$ are more effective in cell survival $^{(47,48)}$. Further studies are needed to address the involvement of p38 MAPK and JNK isoform stimulation and ERK1/2 inactivation in the neuroprotective effect of BJ. For instance, in the case of $\mathrm{H}_{2} \mathrm{O}_{2}$-induced inactivation of $\mathrm{MEK} 1 / 2$ and ERK1/2, BJ could have prevented these effects of the oxidant stress by blocking MAPK activity; future studies should address this possibility. 
One of the first hypotheses that come to mind to explain the neuroprotective action of $\mathrm{BJ}$ relates to direct antioxidant mechanisms $^{(49)}$. Indeed, the total phenolic content in BJ was increased more than four times compared with $\mathrm{NJ}$, with such compounds being well known for their antioxidant potential $^{(26)}$. For example, epigallocatechin-3-gallate, a phenolic compound from green tea, was recently found to accumulate in the mitochondria where it acts locally as a free radical scavenger to protect neurons ${ }^{(50)}$. In view of the heightened content in BJ, such an accumulation of phenolic compounds in the mitochondria may have been enhanced, with an expected increase in the free radical-scavenging capacity to protect neurons against oxidative stress. Moreover, the biotransformation of blueberry juice not only increases its phenolic content, but also produces novel compounds ${ }^{(26)}$. Given that BJ was added at a gallic acid equivalent that was equal to that of $\mathrm{NJ}$, one interesting possibility is that these novel compounds possess more potent antioxidant properties that could have contributed to protect neurons, as opposed to components of NJ. This hypothesis should be tested once the novel bioactive compounds in BJ are identified.

Another hypothesis to explain the observed BJ neuroprotective activity is the pro-oxidant hypothesis ${ }^{(51)}$. Indeed, some phenolic compounds present in BJ may act as weak oxidants, thereby activating antioxidant defence mechanisms as observed herein for $\mathrm{CAT}^{(52)}$. If neuronal cells defence systems were so prepared by $\mathrm{BJ}$ before $\mathrm{H}_{2} \mathrm{O}_{2}$ was added, $\mathrm{H}_{2} \mathrm{O}_{2}$ induced deleterious effects may thus have been inhibited. However, the pro-oxidant hypothesis also raises a limitation in our study. Indeed, some phenolic compounds, such as EGCG, can be oxidised in culture media, and form $\mathrm{H}_{2} \mathrm{O}_{2}^{(51)}$. Therefore, neurons pretreated with $\mathrm{BJ}$ and $\mathrm{NJ}$ may have been exposed to concentrations of $\mathrm{H}_{2} \mathrm{O}_{2}$ greater than that expected based on the amounts added in our experimental protocols. However, this increased $\mathrm{H}_{2} \mathrm{O}_{2}$ concentration does not appear to have had a significant deleterious impact because $\mathrm{H}_{2} \mathrm{O}_{2}$-induced cell death did not increase in $\mathrm{NJ}$ or BJ groups. On the contrary, if anything, such considerations only further highlight the significant beneficial neuroprotective effect of BJ, which may well be related to the changes in blueberry juice composition after the biotransformation.

In summary, the results of the present study indicate that $\mathrm{BJ}$ possesses a strong neuroprotective potential against $\mathrm{H}_{2} \mathrm{O}_{2}$-induced oxidative stress in the $\mathrm{N} 2 \mathrm{a}$ neuronal cell line in vitro. $\mathrm{BJ}$ increased antioxidant enzyme activity as well as p38 MAPK and JNK activation while blocking $\mathrm{H}_{2} \mathrm{O}_{2}$-induced ERK1/2 activity modifications. We speculate that it is a combination of these various actions of BJ that contributed to protect neurons against cell death induced by oxidative stress. Although the active principles and their precise mechanisms of action remain to be identified, BJ may represent a promising approach to prevent and treat neurodegenerative disorders, and it may represent a source of novel therapeutic agents against these diseases.

\section{Acknowledgements}

The present study was funded by the Canadian Institutes of Health Research, Atlantic Innovation Funds, Atlantic Canada Opportunities Agency and Institute of Nutraceuticals and Functional Foods, a Strategic Research Group of the
Quebec 'Fonds de recherche sur la nature et les technologies'. T. V. conducted all the experiments, performed data analysis and drafted the paper. C. M., C. R., P. S. H. supervised and provided technical support for the study and revised the manuscript. The authors have no conflict of interest.

\section{References}

1. Le Forestier N, Lacomblez L \& Meininger V (2008) Parkinson disease and amyotrophic lateral sclerosis. Tauopathies, TDP-43 and SOD mutations. Rev Neurol (Paris) 165, 15-30.

2. Mancuso M, Orsucci D, Siciliano G, et al. (2008) Mitochondria, mitochondrial DNA and Alzheimer's disease. What comes first? Curr Alzheimer Res 5, 457-468.

3. Pratico D (2008) Oxidative stress hypothesis in Alzheimer's disease: a reappraisal. Trends Pharmacol Sci 29, 609-615.

4. Yacoubian TA \& Standaert DG (2008) Targets for neuroprotection in Parkinson's disease. Biochim Biophys Acta 1792, 676-687.

5. Busija DW, Gaspar T, Domoki F, et al. (2008) Mitochondrialmediated suppression of ROS production upon exposure of neurons to lethal stress: mitochondrial targeted preconditioning. Adv Drug Deliv Rev 60, 1471-1477.

6. Cadet J, Douki T \& Ravanat JL (2008) Oxidatively generated damage to the guanine moiety of DNA: mechanistic aspects and formation in cells. Acc Chem Res 41, 1075-1083.

7. Heo HJ, Choi SJ, Choi SG, et al. (2008) Effects of banana, orange, and apple on oxidative stress-induced neurotoxicity in PC12 cells. J Food Sci 73, H28-H32.

8. Pizarro JG, Yeste-Velasco M, Rimbau V, et al. (2008) Neuroprotective effects of SB-415286 on hydrogen peroxide-induced cell death in B65 rat neuroblastoma cells and neurons. Int J Dev Neurosci 26, 269-276.

9. Yang LX, Zhang LJ, Huang KX, et al. (2008) Antioxidant and neuroprotective effects of synthesized sintenin derivatives. J Enzyme Inhib Med Chem 24, 425-431.

10. Valko M, Leibfritz D, Moncol J, et al. (2007) Free radicals and antioxidants in normal physiological functions and human disease. Int J Biochem Cell Biol 39, 44-84.

11. Lindenau J, Noack H, Possel H, et al. (2000) Cellular distribution of superoxide dismutases in the rat CNS. Glia 29, 25-34.

12. Murphy LO \& Blenis J (2006) MAPK signal specificity: the right place at the right time. Trends Biochem Sci 31, $268-275$.

13. Krishna M \& Narang H (2008) The complexity of mitogenactivated protein kinases (MAPKs) made simple. Cell Mol Life Sci 65, 3525-3544.

14. Joseph JA, Shukitt-Hale B \& Lau FC (2007) Fruit polyphenols and their effects on neuronal signaling and behavior in senescence. Ann N Y Acad Sci 1100, 470-485.

15. Galli RL, Shukitt-Hale B, Youdim KA, et al. (2002) Fruit polyphenolics and brain aging: nutritional interventions targeting age-related neuronal and behavioral deficits. Ann N Y Acad Sci 959, 128-132.

16. Joseph JA, Shukitt-Hale B \& Casadesus G (2005) Reversing the deleterious effects of aging on neuronal communication and behavior: beneficial properties of fruit polyphenolic compounds. Am J Clin Nutr 81, 313S-316S.

17. Shukitt-Hale B, Carey AN, Jenkins D, et al. (2007) Beneficial effects of fruit extracts on neuronal function and behavior in a rodent model of accelerated aging. Neurobiol Aging 28, 1187-1194.

18. Ramassamy C (2006) Emerging role of polyphenolic compounds in the treatment of neurodegenerative diseases: a review of their intracellular targets. Eur J Pharmacol 545, $51-64$. 
19. Singh M, Arseneault M, Sanderson T, et al. (2008) Challenges for research on polyphenols from foods in Alzheimer's disease: bioavailability, metabolism, and cellular and molecular mechanisms. J Agric Food Chem 56, 4855-4873.

20. Wang JY, Wen LL, Huang YN, et al. (2006) Dual effects of antioxidants in neurodegeneration: direct neuroprotection against oxidative stress and indirect protection via suppression of glia-mediated inflammation. Curr Pharm Des 12, 3521-3533.

21. Wolfe KL, Kang X, He X, et al. (2008) Cellular antioxidant activity of common fruits. J Agric Food Chem 56, 8418-8426.

22. Duffy KB, Spangler EL, Devan BD, et al. (2008) A blueberryenriched diet provides cellular protection against oxidative stress and reduces a kainate-induced learning impairment in rats. Neurobiol Aging 29, 1680-1689.

23. Shukitt-Hale B, Lau FC, Carey AN, et al. (2008) Blueberry polyphenols attenuate kainic acid-induced decrements in cognition and alter inflammatory gene expression in rat hippocampus. Nutr Neurosci 11, 172-182.

24. McGuire SO, Sortwell CE, Shukitt-Hale B, et al. (2006) Dietary supplementation with blueberry kextract improves survival of transplanted dopamine neurons. Nutr Neurosci 9, 251-258.

25. Lau FC, Bielinski DF \& Joseph JA (2007) Inhibitory effects of blueberry extract on the production of inflammatory mediators in lipopolysaccharide-activated BV2 microglia. J Neurosci Res 85, 1010-1017.

26. Martin L \& Matar C (2005) Increase of antioxidant capacity of the lowbush blueberry (Vaccinium angustifolium) during fermentation by a novel bacterium from the fruit microflora. J Sci Food Agric 85, 1477-1484.

27. Vuong T, Martin L \& Matar C (2006) Antioxidant activity of fermented berry juices and their effects on nitric oxide and tumor necrosis factor-alpha production in macrophage 264.7 gamma $\mathrm{NO}(-)$ cell line. J Food Biochem 30, 249-268.

28. Vuong T, Martineau LC, Ramassamy C, et al. (2007) Fermented Canadian lowbush blueberry juice stimulates glucose uptake and AMP-activated protein kinase in insulin-sensitive cultured muscle cells and adipocytes. Can J Physiol Pharmacol 85, 956-965.

29. Vuong T, Benhaddou-Andaloussi A, Brault A, et al. (2009) Antiobesity and antidiabetic effects of biotransformed blueberry juice in KKA(y) mice. Int J Obes (Lond) 33, 1166-1173.

30. Matchett MD, MacKinnon SL, Sweeney MI, et al. (2006) Inhibition of matrix metalloproteinase activity in DU145 human prostate cancer cells by flavonoids from lowbush blueberry (Vaccinium angustifolium): possible roles for protein kinase C and mitogen-activated protein-kinase-mediated events. $J$ Nutr Biochem 17, 117-125.

31. Sun AY, Wang Q, Simonyi A, et al. (2008) Botanical phenolics and brain health. Neuromol Med 10, 259-274.

32. Seeram NP, Aviram M, Zhang Y, et al. (2008) Comparison of antioxidant potency of commonly consumed polyphenol-rich beverages in the United States. J Agric Food Chem 56, 1415-1422.

33. Fatokun AA, Stone TW \& Smith RA (2008) Oxidative stress in neurodegeneration and available means of protection. Front Biosci 13, 3288-3311.

34. Fourquet S, Huang ME, D'Autreaux B, et al. (2008) The dual functions of thiol-based peroxidases in $\mathrm{H}_{2} \mathrm{O}_{2}$ scavenging and signaling. Antioxid Redox Signal 10, 1565-1576.
35. Whittemore ER, Loo DT, Watt JA, et al. (1995) A detailed analysis of hydrogen peroxide-induced cell death in primary neuronal culture. Neuroscience 67, 921-932.

36. Filiz G, Caragounis A, Bica L, et al. (2008) Clioquinol inhibits peroxide-mediated toxicity through up-regulation of phosphoinositol-3-kinase and inhibition of p53 activity. Int J Biochem Cell Biol 40, 1030-1042.

37. Kemmerling U, Munoz P, Muller M, et al. (2007) Calcium release by ryanodine receptors mediates hydrogen peroxideinduced activation of ERK and CREB phosphorylation in N2a cells and hippocampal neurons. Cell Calcium 41, 491-502.

38. Kolla N, Wei Z, Richardson JS, et al. (2005) Amitriptyline and fluoxetine protect PC12 cells from cell death induced by hydrogen peroxide. J Psychiatry Neurosci 30, 196-201.

39. Ditelberg JS, Sheldon RA, Epstein CJ, et al. (1996) Brain injury after perinatal hypoxia-ischemia is exacerbated in copper/zinc superoxide dismutase transgenic mice. Pediatr Res 39, 204-208.

40. Mahakunakorn P, Tohda M, Murakami Y, et al. (2005) Effects of Choto-san and its related constituents on endogenous antioxidant systems. Biol Pharm Bull 28, 53-57.

41. Amazzal L, Lapotre A, Quignon F, et al. (2007) Mangiferin protects against 1-methyl-4-phenylpyridinium toxicity mediated by oxidative stress in N2A cells. Neurosci Lett 418, 159-164.

42. Kim SR, Park MJ, Lee MK, et al. (2002) Flavonoids of Inula britannica protect cultured cortical cells from necrotic cell death induced by glutamate. Free Radic Biol Med 32, 596-604.

43. Wu XJ, Zheng YJ, Cui YY, et al. (2007) Propofol attenuates oxidative stress-induced PC12 cell injury via p38 MAP kinase dependent pathway. Acta Pharmacol Sin 28, 1123-1128.

44. Colognato R, Laurenza I, Fontana I, et al. (2006) Modulation of hydrogen peroxide-induced DNA damage, MAPKs activation and cell death in $\mathrm{PC} 12$ by ergothioneine. Clin Nutr 25, $135-145$.

45. Caunt CJ, Armstrong SP, Rivers CA, et al. (2008) Spatiotemporal regulation of ERK2 by dual specificity phosphatases. J Biol Chem 283, 26612-26623.

46. Nitta RT, Chu AH \& Wong AJ (2008) Constitutive activity of JNK2 alpha2 is dependent on a unique mechanism of MAPK activation. J Biol Chem 283, 34935-34945.

47. Gutierrez-Sanmartin D, Varela-Ledo E, Aguilera A, et al. (2008) Implication of p38 mitogen-activated protein kinase isoforms (alpha, beta, gamma and delta) in CD4 + T-cell infection with human immunodeficiency virus type I. J Gen Virol 89, 1661-1671.

48. Lin T, Mak NK \& Yang MS (2008) MAPK regulate p53-dependent cell death induced by benzo $[a]$ pyrene: involvement of p53 phosphorylation and acetylation. Toxicology 247, 145-153.

49. Dinkova-Kostova AT \& Talalay P (2008) Direct and indirect antioxidant properties of inducers of cytoprotective proteins. Mol Nutr Food Res 52, Suppl. 1, S128-S138.

50. Schroeder EK, Kelsey NA, Doyle J, et al. (2008) Green tea epigallocatechin 3-gallate accumulates in mitochondria and displays a selective anti-apoptotic effect against inducers of mitochondrial oxidative stress in neurons. Antioxid Redox Signal 11, 469-480.

51. Halliwell B (2008) Are polyphenols antioxidants or prooxidants? What do we learn from cell culture and in vivo studies? Arch Biochem Biophys 476, 107-112.

52. Halliwell B (2007) Dietary polyphenols: good, bad, or indifferent for your health? Cardiovasc Res 73, 341-347. 